\title{
ANALISIS FAKTOR-FAKTOR YANG MEMPENGARUHI EKSPOR TEH INDONESIA KE MALAYSIA
}

\section{Isal Rahmatul Putri, Wiwin Priana, Muhammad Wahed}

Universitas Pembangunan Nasional (UPN) Veteran Jawa Timur, Indonesia

Email : isalrahmatulputri13@gmail.com,wiwinpriana10@gmail.com, muhammadwahed124@gmail.com

\begin{tabular}{ll}
\hline INFO ARTIKEL & ABSTRACT \\
\hline Diterima & The current era of globalization is inseparable from \\
6 Juni 2021 & international trade activities. International trade plays \\
Direvisi & an important role for developing countries. Tea \\
10 Juni 2021 & commodities play an important role for the Indonesian \\
Disetujui & economy, especially in terms of providing jobs, providing \\
21 Juni 2021 & income and also increasing foreign exchange. The \\
\hline Keywords: & purpose of this study is to analyze and find out if tea \\
export; & production affects Indonesian tea exports to Malaysia. To \\
production & analyze and find out if the area of land affects the export \\
& of Indonesian tea to Malaysia. Analyze and find out if the \\
& rupiah exchange rate affects Indonesian tea exports to \\
& Malaysia. And to analyze and find out if Malaysia's GDP \\
& affects Indonesia's tea exports to Malaysia. The method \\
& performed in this study is by quantitative approach. The \\
& data analysis techniques used in this study were tested \\
& using several linear regression analyses with the \\
& Ordinary Least Square (OLS) model. From the data \\
& processing above can be known together that Variavel \\
Independent Production, Land Area, Rupiah Exchange \\
Rate, and GDP Malaysia has a simultaneous and \\
tangible effect on dependent variables of Indonesian Tea \\
Exports to Malaysia during the period 2008-2019. \\
However, otherwise all independent variables have a \\
significant effect on dependent variables.
\end{tabular}

\section{ABSTRAK}

Era globalisasi saat ini tidak dapat dipisahkan dari kegiatan perdagangan internasional. Perdagangan internasional mempunyai peranan yang penting untuk negara berkembang. Komoditas teh memiliki peran cukup signifikan bagi perekonomian Indonesia, terlebih dalam hal penyediaan lapangan pekerjaan, memberi pendapatan dan juga menambah devisa. Tujuan penelitihan ini adalah untuk menganalisis dan mengetahui apakah produksi teh berpengaruh terhadap ekspor teh Indonesia ke Malaysia. Untuk menganalisis

$\begin{array}{ll}\text { How to cite: } & \text { Putri Isal Rahmatul, dkk (2021) Analisis Faktor-Faktor yang Mempengaruhi Ekspor Teh Indonesia } \\ & \text { ke Malaysia . Jurnal Syntax Admiration 2(6). https://doi.org/10.46799/jsa.v2i6.242 } \\ \text { E-ISSN: } & 2722-5356 \\ \text { Published by: } & \text { Ridwan Institute }\end{array}$


Kata Kunci:

ekspor; ekonomi; produksi teh

\begin{abstract}
dan mengetahui apakah luas lahan berpengaruh terhadap ekspor teh Indonesia ke Malaysia. Untuk menganalisis dan mengetahui apakah kurs rupiah berpengaruh terhadap ekspor teh Indonesia ke Malaysia. Serta untuk menganalisis dan mengetahui apakah GDP Malaysia berpengaruh terhadap ekspor teh Indonesia ke Malaysia. Metode yang dilakukan dalam penelitian ini adalah dengan pendekatan kuantitatif. Teknik analisis data yang digunakan dalam penelitihan ini diuji dengan menggunakan analisis regresi linier berganda dengan model Ordinary Least Square (OLS). Dari hasil pengolahan data diketahui bahwa ketiga variabel ( produksi, kurs rupiah, dan GDP Malaysia) memberikan kontribusi terhadap peningkatan ekspor teh Indonesia ke Malaysia.
\end{abstract}

\section{Pendahuluan}

Era globalisasi saat ini tidak dapat dipisahkan dari kegiatan perdagangan internasional. Perdagangan internasional mempunyai peranan yang penting untuk negara berkembang. Indonesia adalah salah satu negara berkembang yang diharapkan untuk melakukan perdagangan internasional khususnya ekspor yang dapat menjadi penggerak ekonomi nasional dan meningkatkan pendapatan devisa (Suminar \& Hms, 2019).

Kegiatan ekspor di Indonesia dibagi menjadi 2 jenis, yaitu: 1) migas; dan 2) nonmigas, sektor non migas dibagi menjadi 3 antara lain sektor industri, sektor pertambangan, dan sektor pertanian. Salah satu sub sektor pertanian yang cukup besar potensinya adalah sub sektor perkebunan. Salah satu komoditas perkebunan di Indonesia adalah komoditas teh.

Komoditas teh memiliki peran cukup signifikan bagi perekonomian Indonesia, terlebih dalam hal penyediaan lapangan pekerjaan, memberi pendapatan dan juga menambah devisa. Sebagian besar komoditas teh di Indonesia diekspor dan hanya sebagian kecil saja yang dipasarkan di dalam negeri. Sehingga teh menjadi salah satu komoditi andalan ekspor indonesia. Berikut dapat dilihat perkembangan ekspor teh Indonesia.

Penelitian mengenai GDP negara tujuan dan ekspor teh Indonesia yang dilakukan oleh (Sidabalok, 2017) menjelaskan bahwa GDP negara pengimpor berpengaruh positif dan signifikan terhadap ekspor teh Indonesia. Namun, penelitian yang dilakukan oleh (El Hasanah, 2018) menyimpulkan bahwa GDP negara tujuan berpengaruh positif dan tidak signifikan terhadap ekspor teh Indonesia. Sedangkan apabila GDP suatu negara semakin besar maka menunjukkan keadaan perekonomian suatu negara tersebut semakin baik dengan diiringi oleh pendapatan negara tersebut yang semakin meningkat (Pambudi \& Budiningharto, 2011).

Beberapa penelitian yang membahas mengenai nilai tukar mata uang asing dan ekspor teh Indonesia yang telah dilakukan oleh (Mejaya et al., 2016), (Ginting, 2017) 
menjelaskan bahwa nilai tukar berpengaruh negatif dan signifikan terhadap ekspor teh Indonesia. Sedangkan pendapat dari (El Hasanah, 2018), (Monita \& Hasmarini, 2021) dan (Zakariya et al., 2016) menerangkan bahwa nilai tukar mata uang asing tidak berpengaruh signifikan terhadap ekspor teh Indonesia.

Penelitian tentang luas lahan terhadap ekspor teh indonesia yang dilakukan oleh (Suryanto \& Sasana, 2017) menyimpulkan bahwa luas lahan berpengaruh positif dan signifikan terhadap ekspor teh Indonesia. Namun, penelitian yang dilakukan (Monita \& Hasmarini, 2021) menerangkan bahwa luas lahan berpengaruh positif dan tidak signifikan terhadap ekspor teh Indonesia.

Beberapa penelitian membahas mengenai produksi dan ekspor teh Indonesia yang dilakukan oleh (Sevianingsih et al., 2016), (Mejaya et al., 2016) menjelaskan bahwa produksi berpengaruh positif tetapi tidak signifikan terhadap volume ekspor. Namun penelitian yang dilakukan oleh (Suminar \& Hms, 2019), (Kusuma et al., n.d.) menerangkan bahwa terdapat hubungan positif dan signifikan antara produksi terhadap ekspor teh indonesia. Ketika produksi meningkat maka persediaan akan meningkat dan ekspor juga akan meningkat, sebaliknya jika produksi menurun maka ekspor juga akan menurun.

Hasil penelitian terdahulu sebagai masukan dan referensi serta bahan pengkajian yang terkait dengan judul, tema, atau topik skripsi yang diajukan:

Penelitian yang dilakukan oleh (Saragih et al., 2020) dengan judul Analisis Faktor-Faktor Yang Mempengaruhi Volume Ekspor Teh Indonesia Dalam Kurun Waktu 1987-2016. Hasil penelitian menunjukkan faktor produksi, harga teh dalam negeri, dan konsumsi teh dalam negeri berpengaruh signifikan terhadap volume ekspor teh. Dan luas lahan, harga internasional teh dan kurs Rupiah terhadap Dollar Amerika Serikat berpengaruh tidak signifikan terhadap volume ekspor teh Indonesia.

Penelitian selanjutnya dilakukan oleh (Yanita et al., 2019) dengan judul Pengaruh Luas Lahan, Kurs Dollar Amerika, Indeks Harga Perdagangan Besar terhadap Ekspor Teh Indonesia Tahun 2000-2015. Variabel independen dalam penelitian ini, yaitu luas lahan, kurs dollar Amerika dan Indeks Harga Perdagangan Besar (IHPB), variabel dependen yaitu ekspor teh indonesia. Hasil dari penelitian ini menyimpulkan bahwa luas lahan, kurs dollar amerika dan Indeks Harga Perdagangan Besar (IHPB) berpengaruh positif dan signifikan terhadap ekspor teh Indonesia tahun 2000-2015.

Penelitian yang dilakukan oleh (Suminar \& Hms, 2019) tentang Analisis FaktorFaktor Yang Mempengaruhi Produksi, Harga Teh Internasional Dan Nilai Tukar Terhadap Volume Ekspor Teh Indonesia. Hasil penelitian ini menyimpulkan bahwa variabel produksi berpengaruh signifikan terhadap ekspor teh di Indonesia periode tahun 1992-2016, dan variabel harga dan nilai tukar tidak berpengaruh signifikan secara statistik terhadap ekspor teh di Indonesia periode tahun 1992-2016.

Penelitian yang yang sama dilakukan (El Hasanah, 2018) yang berjudul Analisis Faktor yang Mempengaruhi Volume Ekspor Teh Indonesia ke Jerman Tahun 19902015. Variabel dependen dalam penelitian ini adalah volume ekspor teh Indonesia ke Jerman. Variabel independen yaitu GDP, kurs, dan harga teh. Hasil dari penelitian ini 
menyimpulkan bahwa GDP berpengaruh positif dan tidak signifikan terhadap volume ekspor teh Indonesia ke Jerman, kurs berpengaruh negatif dan tidak signifikan terhadap volume ekspor teh Indonesia ke Jerman, dan harga teh berpengaruh negatif dan signifikan terhadap volume ekspor teh Indonesia ke Jerman.

Penelitian yang dilakukan (Mejaya et al., 2016) dengan judul Pengaruh Produksi, Harga Teh Internasional dan Nilai Tukar Terhadap Volume Ekspor Teh Indonesia. Berdasarkan hasil penelitian menunjukkan bahwa variabel produksi berpengaruh positif dan tidak signifikan terhadap volume ekspor teh Indonesia. Variabel harga internasional berpengaruh negatif dan tidak signifikan terhadap volume ekspor teh Indonesia, dan variabel nilai tukar berpengaruh negatif dan signifikan terhadap volume ekspor teh Indonesia.

Penelitian yang sama dilakukan oleh (Sevianingsih et al., 2016) dengan judul Pengaruh Produksi, Harga Teh Internasional dan Nilai Tukar Terhadap Volume Ekspor Teh Indonesia. Berdasarkan hasil penelitian menunjukkan bahwa variabel Produksi (X1) memiliki hasil positif dan berpengaruh tidak signifikan, Harga Teh Internasional (X2) memiliki hasil negatif dan berpengaruh tidak signifikan, sedangkan Nilai Tukar Rupiah terhadap US Dollar (X3) memiliki hasil negatif dan berpengaruh signifikan terhadap Volume Ekspor Teh Indonesia (Y). Namun dipenelitian sebelumnya belum disebutkan faktor lain yang dapat mempengaruhi Ekspor Teh Indonesia, oleh karena itu peneliti membuat penelitian selanjutnya bahwa Kurs Rupiah dan GDP mempengaruhi ekspor Teh Indonesia ke Malaysia.

Melihat fenomena tersebut, ekspor teh merupakan salah satu sumber pendapatan devisa negara. ekspor teh Indonesia terbesar adalah ke Malaysia, dapat dikatakan kebutuhan Malaysia akan teh Indonesia begitu besar. Sehingga dari alasan tersebut peneliti tertarik melakukan penelitian mengenai "Analisis Faktor-Faktor Yang Mempengaruhi Ekspor Teh Indonesia Ke Malaysia”.

Berdasarkan latar belakang dan dengan rumusan masalah diatas, maka yang menjadi tujuan penelitian ini adalah untuk menganalisis dan mengetahui apakah produksi teh berpengaruh terhadap ekspor teh Indonesia ke Malaysia. Untuk menganalisis dan mengetahui apakah luas lahan berpengaruh terhadap ekspor teh Indonesia ke Malaysia. Untuk menganalisis dan mengetahui apakah kurs rupiah berpengaruh terhadap ekspor teh Indonesia ke Malaysia. Serta untuk menganalisis dan mengetahui apakah GDP Malaysia berpengaruh terhadap ekspor teh Indonesia ke Malaysia.

\section{Metode Penelitian}

Penelitian ini dilakukan menggunakan pendekatan penelitian kuantitatif yang merupakan suatu penelitian ilmiah yang sistematis terhadap bagian-bagian dan fenomena serta hubungan-hubungannya (Wahidmurni, 2017) Metode penelitian kuantitatif merupakan suatu cara yang digunakan untuk menjawab masalah penelitian yang berkaitan dengan data berupa angka dan program statistik (Wahidmurni, 2017). Penelitian ini dilakukan untuk menganalisis pengaruh produksi teh, luas lahan, kurs 
rupiah,dan GDP Malaysia terhadap ekspor teh Indonesia ke Malaysia tahun 2008 sampai 2019.

Teknik yang digunakan pada penelitian ini adalah metode dokumentasi data sekunder yang diperoleh dari beberapa instansi terkait dari data yang dibutuhkan dalam penelitian ini. Metode pengumpulan data dalam penelitian ini dengan mengunduh data kuantitatif, berupa data sekunder yang diperoleh dari situs Badan Pusat Statistik (BPS) dan situs The World Bank pada periode 2008-2019.

\section{Hasil dan Pembahasan}

\section{A. Hasil Penelitian}

1. Perkembangan Ekspor Teh Indonesia

Ekspor teh menjadi sektor pendukung perekonomian di Indonesia yang cukup menguntungkan hingga saat ini. Berikut ini adalah perkembangan ekspor teh Indonesia periode tahun 2008 sampai dengan 2019 pada tabel 1.

Tabel 1

\begin{tabular}{ccc}
$\begin{array}{c}\text { Perkembangan Ekspor Teh Indonesia Tahun 2008-2019 } \\
\text { Tahun }\end{array}$ & $\begin{array}{c}\text { Ekspor Teh } \\
\text { (Ton) }\end{array}$ & $\begin{array}{c}\text { Perkembangan } \\
(\%)\end{array}$ \\
\hline 2008 & 96210 & - \\
\hline 2009 & 92304 & $-0,041$ \\
\hline 2010 & 87101 & $-0,056$ \\
\hline 2011 & 75450 & $-0,134$ \\
\hline 2012 & 70071 & $-0,071$ \\
\hline 2013 & 70842 & 0,011 \\
\hline 2014 & 66399 & $-0,063$ \\
\hline 2015 & 61915 & $-0,068$ \\
\hline 2016 & 51319 & $-0,171$ \\
\hline 2017 & 54187 & 0,056 \\
\hline 2018 & 49038 & $-0,095$ \\
\hline 2019 & 42811 & $-0,127$ \\
\hline Sumber: BPS Jatim, 2020 (data diolah)
\end{tabular}

Dari tabel 1 dapat diketahui bahwa perkembangan ekspor teh Indonesia pada tahun 2008 sampai 2019 terus mengalami penurunan dengan perkembangan terendah terjadi pada tahun 2016 yakni sebesar $-0,16 \%$ dan perkembangan tertinggi pada tahun 2017 sebesar $0,056 \%$. Hal ini sebabkan oleh beberapa negara tujuan ekspor teh indonesia diambil alih oleh negara produsen teh lainnya termasuk Malaysia. Hal ini membuat permintaan teh indonesia menurun. 
2. Perkembangan Produksi Teh

\section{Tabel 2}

Produksi Teh Di Indonesia Tahun 2008-2019

\begin{tabular}{ccc}
\hline Tahun & $\begin{array}{c}\text { Produksi } \\
\text { (ton) }\end{array}$ & $\begin{array}{c}\text { Perkembangan } \\
(\%)\end{array}$ \\
\hline 2008 & 153971 & - \\
\hline 2009 & 152588 & $-0,009$ \\
\hline 2010 & 151012 & $-0,010$ \\
\hline 2011 & 146603 & $-0,029$ \\
\hline 2012 & 143413 & $-0,022$ \\
\hline 2013 & 145855 & 0,017 \\
\hline 2014 & 142724 & $-0,021$ \\
\hline 2015 & 143609 & 0,006 \\
\hline 2016 & 138771 & $-0,034$ \\
\hline 2017 & 140423 & 0,012 \\
\hline 2018 & 140237 & $-0,001$ \\
\hline 2019 & 128724 & $-0,082$ \\
\hline
\end{tabular}

Sumber: BPS Jatim, 2020 (data diolah)

Berdasarkan tabel 2 terlihat bahwa perkembangan produksi teh di Indonesia dari tahun 2008 sampai 2019 mengalami fluktuasi, dengan perkembangan tertinggi pada tahun 2013 sebesar 0,017\% dan yang terendah tahun 2019 sebesar $-0,082 \%$. Perkembangan produksi teh tersebut dipengaruhi oleh faktor-faktor produksi, terdapat empat kelompok dasar faktor produksi, yaitu sumber daya manusia, sumber daya alam, modal, dan manajemen (Saleh Mejaya dkk, 2016).

3. Perkembangan Kurs Rupiah

Kurs selalu mengalami perubahan terus menerus. Perubahan kurs dapat menguntungkan bahkan merugikan beberapa pihak. Pada penelitian ini mengamati perubahan kurs rupiah pada tahun 2008 hingga tahun 2019. Dibawah ini adalah tabel yang menunjukkan perkembangan kurs rupiah sebagai berikut:

Tabel 3

Kurs Rupiah Tahun 2008-2019

\begin{tabular}{ccc}
\hline Tahun & $\begin{array}{c}\text { Kurs Rupiah } \\
(\mathbf{R p})\end{array}$ & Perkembangan \\
\hline 2008 & 10.950 & - \\
\hline 2009 & 9.400 & $-14 \%$ \\
\hline 2010 & 8.991 & $-4 \%$ \\
\hline 2011 & 9.068 & $1 \%$ \\
\hline 2012 & 9.670 & $7 \%$ \\
\hline 2013 & 12.189 & $26 \%$ \\
\hline 2014 & 12.440 & $2 \%$ \\
\hline 2015 & 13.795 & $11 \%$ \\
\hline 2016 & 13.436 & $-3 \%$ \\
\hline 2017 & 13.548 & $1 \%$ \\
\hline 2018 & 14.481 & $7 \%$ \\
\hline
\end{tabular}




\begin{tabular}{ccc}
\hline 2019 & 13.901 & $-4 \%$ \\
\hline Sumber: BPS Jatim, 2020 (data diolah)
\end{tabular}

Pada tabel 3 dapat dilihat bahwa kurs mengalami perubahan dari tahun ke tahun. Pada kurun waktu 11 tahun terakhir kurs rupiah terus mengalami kenaikan. Kurs rupiah terendah pada tahun 2010 yakni sebesar Rp 8.991 dan kurs rupiah tertinggi pada tahun 2018 sebesar Rp 14.481. Secara garis besar dari tahun ke tahun kurs mengalami kenaikan dan pemerintah berusaha untuk mengontrol agar tidak terjadi kenaikan secara terus menerus sehingga pada beberapa tahun terlihat nilai rupiah menguat terhadap dollar.

Perkembangan kurs rupiah dari tahun 2008 sampai 2019 terus mengalami kenaikan dan hanya 4 kali terjadi penurunan, yaitu pada tahun 2009 sebesar -14\%, penurunan kedua tahun 2010 sebesar $-4 \%$, penurunan ketiga pada tahun 2016 sebesar $-3 \%$, dan terjadi penurunan lagi pada tahun 2019 sebesar $-4 \%$.

4. Perkembangan GDP Malaysia

Gross Domestic Product (GDP) merupakan nilai keseluruhan semua barang dan jasa yang diproduksi dalam wilayah tersebut dalam jangka waktu tertentu (Sukirno, 2011). Salah satu indikator yang sering digunakan para ahli ekonomi untuk mengukur suatu keberhasilan suatu Negara dalam melaksanakan ekonomi adalah Gross Domestic Product (GDP). Berikut adalah perkembangan GDP Malaysia tahun 2008-2019 pada tabel 4:

\section{Tabel 4}

GDP Malaysia Tahun 2008-2019

\begin{tabular}{ccc}
\hline Tahun & $\begin{array}{c}\text { GDP Malaysia } \\
\text { (dalam juta dollar) }\end{array}$ & Perkembangan \\
\hline 2008 & 230.814 & - \\
\hline 2009 & 202.258 & $-12 \%$ \\
\hline 2010 & 255.017 & $26 \%$ \\
\hline 2011 & 297.952 & $17 \%$ \\
\hline 2012 & 314.443 & $6 \%$ \\
\hline 2013 & 323.277 & $3 \%$ \\
\hline 2014 & 338.062 & $5 \%$ \\
\hline 2015 & 301.355 & $-11 \%$ \\
\hline 2016 & 301.255 & $0 \%$ \\
\hline 2017 & 319.112 & $6 \%$ \\
\hline 2018 & 358.715 & $12 \%$ \\
\hline 2019 & 364.681 & $2 \%$ \\
\hline S
\end{tabular}

Sumber: The Word Bank , 2020 (data diolah)

Berdasarkan tabel 5 terlihat bahwa perkembangan GDP Malaysia dari tahun 2008 sampai 2019 terus mengalami kenaikan, dengan perkembangan tertinggi pada tahun 2010 sebesar $26 \%$ dan yang terendah tahun 2009 sebesar $-12 \%$. 


\section{B. Pembahasan}

1. Hasil Analisis Regresi Berganda

Berdasarkan hasil perhitungan pengolahan data dengan bantuan komputer program IBM SPSS versi 16 maka diperoleh persamaan regresi linier berganda sebagai berikut: $\mathrm{Y}=-186597.500+0.844 \mathrm{X} 1+1.365 \mathrm{X} 2-0,483 \mathrm{X} 3-0.076 \mathrm{X} 4$

Berdasarkan persamaan diatas dapat diuraikan sebagai berikut:

B0: Nilai konstanta sebesar -186597.500

Menunjukkan apabila Produksi (X1), Luas Lahan (X2), Kurs Rupiah (X3), dan GDP Malaysia (X4) dianggap konstan maka Ekspor Teh Indonesia Ke Malaysia (Y) akan turun sebesar 186597.500 persen. $\beta 1$ : Koefisien regresi X1 ( $\beta 1)$ : Y= 0.844 Menunjukkan bahwa Produksi (X1) berpengaruh positif, dapat diartikan apabila produksi mengalami peningkatan sebesar 1 persen maka Ekspor Teh Indonesia Ke Malaysia (Y) mengalami peningkatan sebesar 0,844 persen. Dengan asumsi X2, X3, dan X4 Konstan. $\beta 2$ : Koefisien regresi X2 ( $\beta 2): Y=1.36$ Menunjukkan bahwa Luas Lahan (X2) berpengaruh positif, dapat diartikan apabila luas lahan mengalami peningkatan sebesar 1 persen maka Ekspor Teh Indonesia Ke Malaysia (Y) mengalami peningkatan sebesar 1.365 persen. Dengan asumsi X1, X3, dan X4 Konstan. $\beta 3$ : Koefisien regresi X3 ( $\beta 3)$ : $Y=-0,483$

Menunjukkan bahwa Kurs Rupiah (X3) berpengaruh negatif, dapat diartikan apabila kurs rupiah mengalami peningkatan sebesar 1 persen maka Ekspor Teh Indonesia Ke Malaysia (Y) mengalami penurunan sebesar 0,483 persen. Dengan asumsi X1, X2, dan X4 Konstan.

$\beta 4$ : Koefisien regresi $X 4(\beta 4)=-0.076$

Menunjukkan bahwa GDP Malaysia (X4) berpengaruh negatif, dapat diartikan apabila GDP Malaysia mengalami peningkatan sebesar 1 persen maka Ekspor Teh Indonesia Ke Malaysia (Y) mengalami penurunan sebesar 0.079 persen. Dengan asumsi X1, X2, dan X3 Konstan.

2. Hasil Uji Asumsi Klasik (BLUE)

Agar mendapatkan hasil estimasi yang BLUE (Best Linier Unbiased Estimator) maka estimasi tersebut harus memenuhi beberapa asumsi yang berkaitan. Apabila salah satu asumsi tersebut dilanggar, maka persamaan regresi yang diperoleh tidak lagi bersifat BLUE, sehingga pengambilan keputusan melalui uji $\mathrm{F}$ dan uji $\mathrm{t}$ menjadi bias.

a. Uji Normalitas

Uji normalitas adalah bertujuan untuk mengetahui kenormalan distribusi data. Pengujian ini bertujuan untuk mengetahui apakah data yang diambil merupakan data yang normal atau tidak (Puspita \& GHOZALI, 2011). Dalam uji normalitas ini, data akan diuji dengan statistik Kolmogorov-Smirnov. Dasar pengembalian keputusan adalah jika 2-tailed > 0,05 maka model regresi memenuhi asumsi normalitas dan sebaliknya. Selain itu pada pengujian ini juga dengan menggunakan P-P Plot, jika data menyebar disekitar garis diagonal dan mengikuti arah garis diagonal maka menunjukkan pola distribusi normal. 
Adapun hasil yang diperoleh dari pengujian normalitas dapat dilihat pada tabel berikut:

\section{Tabel 6}

Uji Normalitas (One Sample Kolmogrov-Smirnov Test) One-Sample Kolmogorov-Smirnov Test

\begin{tabular}{llr}
\hline \multicolumn{2}{c}{ One-Sample Kolmogorov-Smirnov Test } \\
\hline $\mathrm{N}$ & $\begin{array}{c}\text { Unstandardized } \\
\text { Residual }\end{array}$ \\
Normal Parameters ${ }^{\mathrm{a}}$ & Mean & 12 \\
& Std. Deviation & .0000000 \\
Most Extreme Differences & Absolute & $.141317583 \mathrm{E} 3$ \\
& Positive & .146 \\
Kolmogorov-Smirnov Z & Negative & -.144 \\
Asymp. Sig. (2-tailed) & .507 \\
\hline a. Test distribution is Normal. & .959 \\
\hline
\end{tabular}

Pada uji normalitas residual dikatakan data berdistribusi normal, jika nilai signifikan residual lebih dari 0,05. Diketahui nilai kolmogorov-smirnov sebesar 0,507 dan nilai Asym. Sig (2-tailed) 0,959. Nilai signifikan residual yaitu 0,507 > 0,05 maka dapat disimpulkan bahwa data terdistribusi secara normal.

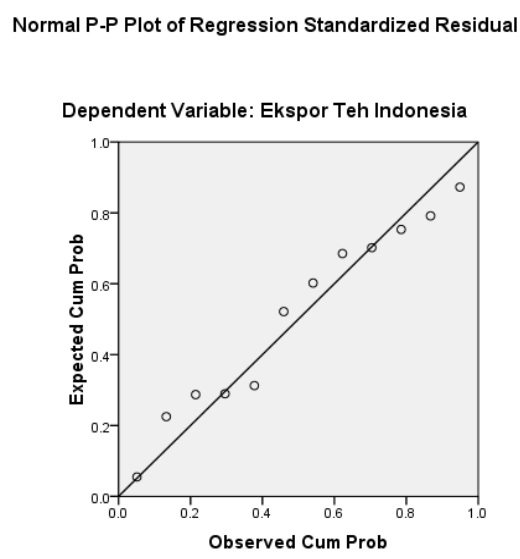

Gambar 1

Uji Normalitas (P-Plot)

Sumber: Output SPSS (Lampiran)

Berdasarkan gambar 1 penyebaran data (titik) pada sumbu diagonal grafik menyebar di sekitar garis diagonal dan mengikuti arah garis diagonal atau grafik histogramnya menunjukkan pola distribusi yang normal, maka model regresi memenuhi asumsi normalitas.

b. Uji Autokorelasi

Autokorelasi muncul karena observasi yang berurutan sepanjang waktu berkaitan satu sama lainnya. Untuk mendekteksi ada atau tidaknya autokorelasi bisa menggunakan Uji Durbin-Watson (DW test). Berdasarkan perhitungan 
pada penelitian ini menggunakan SPSS diperoleh Nilai DW test sebesar 1.447. Dalam persamaan ini jumlah variabel bebas (k) adalah 4 dan banyaknya data (n) adalah 11 sehingga diperoleh nilai DW tabel adalah sebesar $\mathrm{dL}=0,4441$ dan $\mathrm{dU}=2,2833$.

c. Uji Multikolinearitas

Uji multikolinearitas digunakan untuk mengetahui apakah terjadi korelasi yang kuat di antara variable-variabel independen yang diikuti dalam pembentukan model. Untuk mendeteksi apakah ada model regresi linier yang mengalami gejala multikolinearitas dapat diperiksa menggunakan Variance Inflation Factor (VIF) untuk masing-masing variabel independen, yaitu jika suatu variabel independen mempunyai nilai VIF >10 maka telah terjadinya multikolinearitas.

Maka hasil yang diperoleh setelah diadakan pengujian analisis regresi linier berganda diketahui bahwa dari keempat variabel dalam pengujian nilai Pertumbuhan Ekonomi Indonesia, dimana nilai VIF lebih kecil dari 10 sehingga dalam model regresi ini tidak terjadi multikolinearitas.

d. Uji Heteroskedastisitas

Uji heteroskedastisitas digunakan untuk mengetahui ada atau tidaknya penyimpangan asumsi klasik heteroskedastisitas yaitu ketidaksamaan varian dari residual untuk semua pengamatan pada model regresi (Puspita \& GHOZALI, 2011) Pada regresi linier nilai residual tidak boleh ada hubungan dengan variabel bebas $(\mathrm{X})$.

Diperoleh tingkat signifikasi koefisien korelasi Rank Spearman untuk variable terikat pertumbuhan ekonomi, keseluruhan residualnya lebih besar dari 0,05 (tidak signifikan) hal tersebut menunjukkan bahwa antara nilai residual dengan variabel yang menjelaskan tidak mempunyai korelasi yang berarti. Dapat disimpulkan persamaan tersebut tidak terjadi heteroskedastisitas.

3. Pengujian Hipotesis

a. Uji Koefisien Determinasi (R2)

Koefisien (R) dilakukan untuk mengukur kekuatan hubungan antara dua variabel. Koefisien determinasi (R2) dilakukan untuk mengukur seberapa jauh kemampuan model dalam menerangkan variabel dependen. Nilai yang mendekati 1 berati variabel-variabel independennya memberikan hampir semua informasi yang dibutuhkan untuk memprediksi variabel dependen (Puspita \& GHOZALI, 2011). Nilai koefisien determinasi dapat dilihat pada tabel dibawah ini:

Tabel 7

Uji Koefisien Determinasi

\begin{tabular}{ccccc}
\hline Model & $\boldsymbol{R}$ & $\begin{array}{c}\boldsymbol{R} \\
\text { Square }\end{array}$ & $\begin{array}{c}\text { Adjusted } \boldsymbol{R} \\
\text { Square }\end{array}$ & $\begin{array}{c}\text { Std. Error of the } \\
\text { Estimate }\end{array}$ \\
\hline $\mathbf{1}$ & $990^{\mathrm{a}}$ &, 981 & 970 & 3025,07600 \\
\hline & Sumber: Output & SPSS(Lampiran 5) &
\end{tabular}


Koefisien determinasi sebesar 0,990 hal ini menunjukkan bahwa besarnya variabel Pertumbuhan Ekonomi yang bisa diterangkan oleh variable Produksi (X1), Luas Lahan (X2), Kurs Rupiah (X3), dan GDP Malaysia (X4) sebesar $99,0 \%$ dan sisanya sebesar 2,0 \% dipengaruhi oleh faktor lain yang tidak tambak modelnya.

b. Uji F

Uji f digunakan untuk mengetahui secara simultan (bersama-sama) pengaruh variabel bebas terhadap variabel terikatnya. Dari perhitungan dengan program IBM SPSS 16.0 diperoleh hasil perhitungan ANOVA sebagai berikut:

Tabel 8

Uji F Simultan (ANOVA)

\begin{tabular}{|c|c|c|c|c|c|c|}
\hline \multicolumn{2}{|c|}{ Model } & \multirow{2}{*}{$\begin{array}{c}\text { Sum of Squares } \\
3.258 \mathrm{E} 9\end{array}$} & \multirow{2}{*}{$\frac{\text { df }}{4}$} & \multirow{2}{*}{$\begin{array}{c}\text { Mean Square } \\
8.144 \mathrm{E} 8\end{array}$} & \multirow{2}{*}{$\frac{\mathbf{F}}{88.995}$} & \multirow{2}{*}{$\frac{\text { Sig. }}{.000^{\mathrm{a}}}$} \\
\hline 1 & Regression & & & & & \\
\hline & Residual & $6.406 \mathrm{E} 7$ & 7 & 9151084.806 & & \\
\hline & Total & $3.322 \mathrm{E} 9$ & 11 & & & \\
\hline
\end{tabular}

Pada tabel ANOVA diperoleh nilai $\mathrm{F}$ hitung sebesar 88,995 dengan tingkat signifikasi sebesar 0,000 dengan taraf signifikasi 5\% atau $(\alpha=0,05)$ maka nilai sig $0,000<0,005$. Sedangkan nilai $\mathrm{F}$ tabel dengan Degree Of Freedom (DF) adalah 4 (jumlah variabel bebas/k) dan df2 6 (n-k-1) diperoleh F tabel sebesar 4,53. Dari hasil tersebut diketahui bahwa nilai Fhitung 88,995 $\geq$ Ftabel 4,53 sehingga H0 ditolak dan Hi diterima, maka dapat disimpulkan secara bersama-sama produksi, luas lahan, kurs rupiah, dan GDP Malaysia berpengaruh positif terhadap ekspor teh Indonesia ke Malaysia. Dengan dibuktikan pada kurva distribusi uji $\mathrm{F}$ di bawah ini:

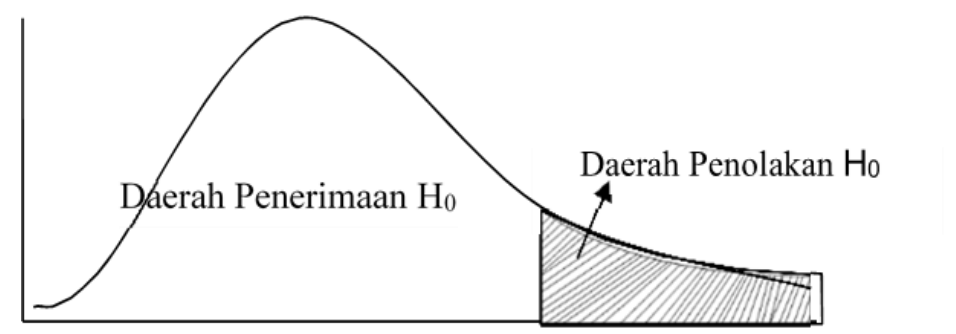

Gambar 2

Kurva Distribusi Uji F

c. Uji t

Uji t dalam persamaan regresi digunakan untuk mengetahui pengaruh signifikasi variabel bebas terhadap variabel terikat secara masing-masing (parsial). Hasil dari uji t dalam penelitian ini dijelaskan sebagai berikut: 
Tabel 9

Uji t Parsial

\begin{tabular}{lccc}
\multicolumn{1}{c}{ Variabel } & T Hitung & T Tabel & Sig. \\
\hline Produksi $(\mathrm{X} 1)$ & 2,606 & 2,446 & 0,035 \\
\hline Luas Lahan $(\mathrm{X} 2)$ & 3,441 & 2,446 & 0,011 \\
\hline Kurs Rupiah $(\mathrm{X} 3)$ & $-0,593$ & 2,446 & 0,572 \\
\hline GDP Malaysia(X4) & $-2,152$ & 2,446 & 0,068
\end{tabular}

Sumber: Output SPSS (Lampiran 5)

Penjelasan hasil output pada tabel 9 uji t parsial apakah adanya pengaruh signifikan pada setiap variabelnya dapat dilihat pada penjabaran berikut ini:

1) Variabel Produksi

Perhitungan secara parsial diperoleh nilai t hitung sebesar 2,606 sedangkan nilai t tabel $(\alpha / 2=0,025)$ dengan Degree Of Freedom (DF) 6 (n$\mathrm{k}-1)$ diperoleh nilai $\mathrm{t}$ table sebesar 2,446. Dari hasil tersebut diketahui bahwa nilai t hitung 2,606 $\geq \mathrm{t}$ tabel 2,446 maka $\mathrm{H} 0$ ditolak dan Ha diterima, dengan nilai signifikansi $0,035<0,05$. Dengan dibuktikan pada kurva distribusi uji t dibawah ini:

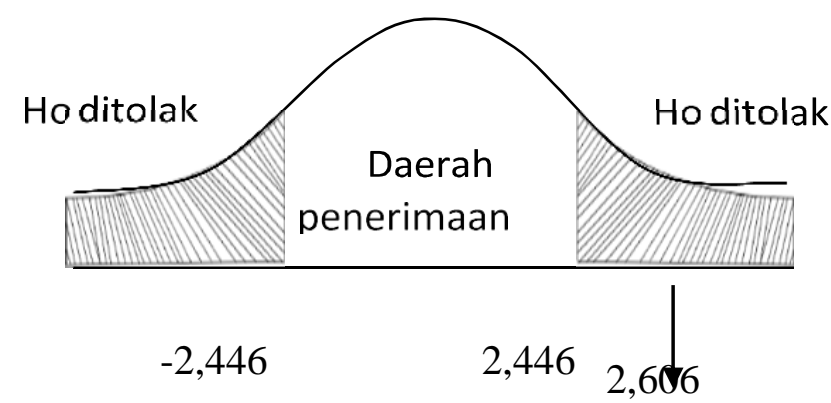

Gambar 3

Kurva Distribusi Uji t Prosuksi

Berdasarkan kurva uji t diatas berada pada daerah penolakan H0 maka dapat disimpulkan secara parsial bahwa variabel produksi berpengaruh positif dan signifikan terhadap ekspor teh Indonesia ke Malaysia..

2) Variabel Kurs Rupiah

Perhitungan secara parsial diperoleh nilai t hitung sebesar $-0,593$ sedangkan nilai t tabel $(\alpha / 2=0,025)$ dengan Degree Of Freedom (DF) 6 (n$\mathrm{k}$-1) diperoleh nilai t tabel sebesar 2,446. Dari hasil tersebut diketahui bahwa nilai thitung $-0,593 \leq \mathrm{t}$ tabel 2,446 maka H0 diterima dan Hi ditolak, dengan nilai signifikansi $0,572>0,05$. Dengan dibuktikan pada kurva distribusi uji t berikut: 


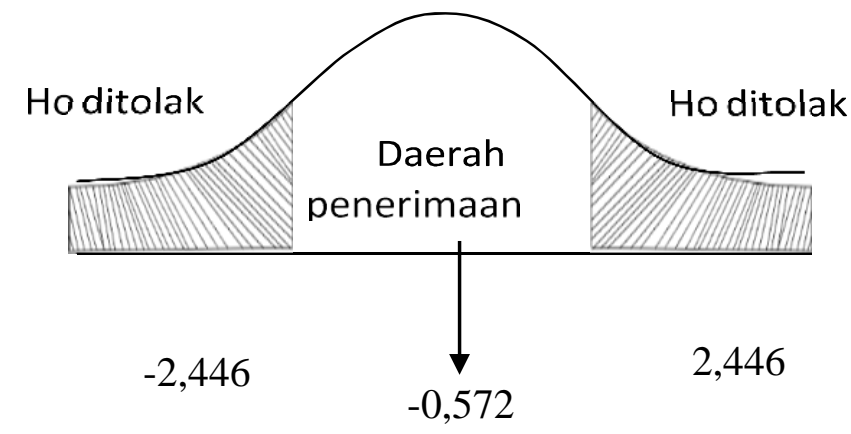

\section{Gambar 5}

Kurva Distribusi Uji t Kurs Rupiah

Berdasarkan kurva Uji t diatas berada pada daerah penerimaan $\mathrm{H} 0$ maka dapat disimpulkan secara parsial variabel kurs rupiah berpengaruh negatif dan tidak signifikan terhadap ekspor teh Indonesia ke Malaysia

3) Variabel GDP Malaysia

Perhitungan secara parsial diperoleh nilai t hitung sebesar -2,152 sedangkan nilai $\mathrm{t}$ tabel $(\alpha / 2=0,025)$ dengan Degree Of Freedom (DF) 6 ( $\mathrm{n}$ $\mathrm{k}$-1) diperoleh nilai $\mathrm{t}$ tabel sebesar 2,446. Dari hasil tersebut diketahui bahwa nilai $\mathrm{t}$ hitung $-2,152 \geq \mathrm{t}$ tabel 2,446 maka H0 diterima dan Hi ditolak, dengan nilai signifikasi $0,068<0,05$. Dengan dibuktikan pada kurva distribusi uji t berikut:

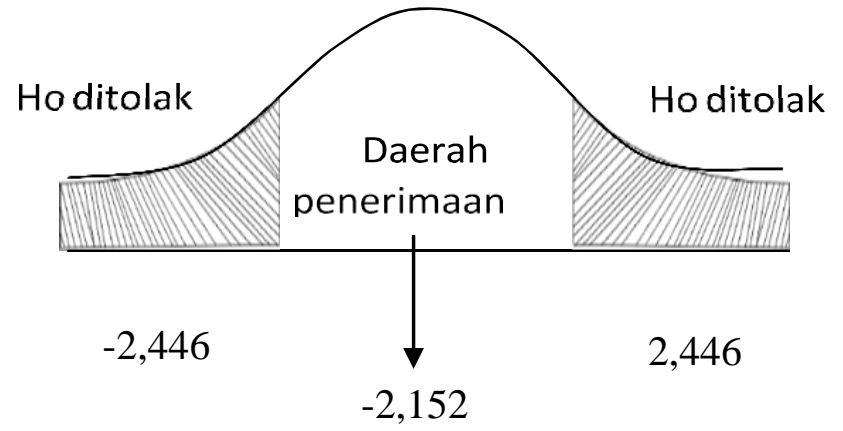

Gambar 6

Kurva Distribusi Uji t GDP Malaysia

Berdasarkan kurva Uji t diatas berada pada daerah penerimaan $\mathrm{H} 0$ maka dapat disimpulkan secara parsial variabel GDP Malaysia berpengaruh negatif dan tidak signifikan terhadap ekspor teh Indonesia ke Malaysia.

Dari hasil pengolahan data diatas dapat diketahui secara bersama-sama bahwa variabel independen produksi, luas lahan, kurs rupiah, dan GDP Malaysia berpengaruh simultan dan nyata terhadap variabel dependen ekspor teh Indonesia ke Malaysia selama periode 2008-2019. Akan tetapi jika secara parsial tidak semua variabel independen berpengaruh signifikan terhadap variabel dependen. 
Variabel Produksi secara parsial berpengaruh positif dan signifikan terhadap ekspor teh Indonesia Ke Malaysia selama periode 2008-2019. Hasil penelitian ini sesuai dengan penelitian yang dilakukan oleh (Kusuma et al., n.d.), (Saragih et al., 2020), dan (Suminar \& Hms, 2019) yang menjelaskan bahwa produksi berpengaruh signifikan terhadap ekspor teh Indonesia. Salfatore (1984) menyatakan bahwa salah satu faktor yang mempengaruhi ekspor dari sisi penawaran adalah kapasitas produksi. (Komalasari, 2009) menyatakan bahwa peningkatan produksi berpengaruh positif terhadap penawaran ekspor suatu komoditas. Sehingga, Semakin banyak jumlah produksi teh, semakin banyak penawaran akan ekspor teh yang mana meningkatkan volume ekspor teh, dan sebaliknya.

Variabel luas lahan secara parsial berpengaruh positif dan signifikan terhadap ekspor teh Indonesia ke Malaysia periode 2008-2019. Hasil penelitihan ini sesuai dengan penelitihan yang dilakukan oleh (Yanita et al., 2019) yang menjelaskan bahwa luas lahan berpengaruh signifikan terhadap ekpor teh Indonesia. Semakin luas lahan perkebunan yang diusahakan maka produksi yang dihasilkan secara kuantitas cenderung meningkat sehingga dapat meningkatkan ekspor teh Indonesia ke Malaysia dan begitu sebaliknya.

Variabel kurs rupiah secara parsial berpengaruh negatif dan tidak signifikan terhadap ekspor teh Indonesia ke Malaysia periode 2008-2019. Adanya pengaruh negatif disebabkan karena tingkat inflasi dalam negeri lebih tinggi dibandingkan pertumbuhan penguatan rupiah terhadap dollar USA (apresiasi) (Lukman \& Krajnc, 2012). Pengaruh negatif namun tidak signifikan berarti bahwa nilai tukar tidak memberikan pengaruh yang berarti pada permintaan ekspor teh atau perubahan yang terjadi tidak memberikan pengaruh yang berbeda bagi permintaan ekspor teh ke Malaysia. hasil penelitihan ini sesuai dengan penelitihan sebelumnya yang dilakukan oleh (Monita \& Hasmarini, 2021), (El Hasanah, 2018) menjelaskan bahwa kurs rupiah tidak mempengaruhi volume ekspor teh Indonesia.

Variabel GDP Malaysia secara parsial tidak berpengaruh signifikan terhadap ekspor teh Indonesia ke Malaysia periode 2008-2019. Hal ini menunjukkan bahwa kenaikan GDP Malaysia tidak akan mempengaruhi volume ekspor teh Indonesia ke Malaysia. Peningkatan pendapatan masyarakat tidak berpengaruh dengan peningkatan atau penurunan permintaan teh indonesia. Hal ini sesuai dengan penelitihan yang dilakukan oleh (El Hasanah, 2018) yang menjelaskan bahwa GDP negara importir tidak mempengaruhi volume ekpor teh Indonesia.

\section{Kesimpulan}

Berdasarkan hasil analisis yang telah diuraikan pada Bab IV, maka dapat diambil kesimpulan. Setelah dilakukan uji statistik diperoleh bahwa Produksi, Kurs Rupiah, dan GDP Malaysia secara simultan berpengaruh positif terhadap Ekspor Teh Indonesia Ke Malaysia periode tahun 2008-2019 yang artinya secara bersama-sama dari keempat variabel memberikan kontribusi terhadap peningkatan Ekspor Teh Indonesia Ke Malaysia. 
Secara parsial produksi berpengaruh positif dan signifikan terhadap ekspor teh Indonesia Ke Malaysia tahun 2008-2019. hal tersebut digambarkan dengan banyaknya permintaan teh Indonesia di Malaysia disetiap tahunnya yang akan mendorong peningkatan produksi teh dalam negeri. Peningkatan produktivitas tersebut akan membuat ekspor teh Indonesia menjadi meningkat.

Secara parsial kurs rupiah berpengaruh negatif dan signifikan terhadap ekspor teh Indonesia Ke Malaysia tahun 2008-2019. hal ini menunjukkan Perubahan kurs berpengaruh pada permintaaan ekspor teh. Adanya hubungan negatif disebabkan karena naiknya kurs rupiah, menyebabkan harga barang ekspor semakin mahal, sehingga permintaan terhadap barang ekspor turun.

GDP Malaysia secara parsial berpengaruh negatif dan tidak signifikan terhadap ekspor teh Indonesia Ke Malaysia tahun 2008-2019 hal ini disebabkan karena negara produsen teh lainnya mengambil alih beberapa pasar utama teh Indonesia termasuk Malaysia. Banyaknya pesaing teh Indonesia dengan kualitas baik dan harga yang lebih terjangkau membuat negara importir cenderung memenuhi kebutuhan persediaan teh dengan mengimpor dari negara lain. 


\section{BIBLIOGRAFI}

El Hasanah, L. L. N. (2018). Analisis Faktor Yang Mempengaruhi Volume Ekspor Teh Indonesia Ke Jerman (Tahun 1990-2015).Google Scolar

Ginting, A. M. (2017). Analisis Pengaruh Ekspor Terhadap Pertumbuhan Ekonomi Indonesia. Buletin Ilmiah Litbang Perdagangan, 11(1), 1-20. Google Scolar

Komalasari, A. (2009). Analisis Tentang Pelaksanaan Plant Layout Dalam Usaha Meningkatkan Efisiensi Produksi. Bandung: Universitas Widyatama.Google Scolar

Kusuma, I. W. B. O., Prabawa, P. D., \& Kependudukan, M. S. S. (N.D.). Pengaruh Produksi Teh Terhadap Volume Ekspor Teh Indonesia Tahun 1970-2015 (Analisis Data Statistik Teh Indonesia).Google Scholar

Lukman, R., \& Krajnc, M. (2012). Exploring Non-Traditional Learning Methods In Virtual And Real-World Environments. Journal Of Educational Technology \& Society, 15(1), 237-247. Google Scholar

Mejaya, A. S., Fanani, D., \& Mawardi, M. K. (2016). Pengaruh Produksi, Harga Internasional, Dan Nilai Tukar Terhadap Volume Ekspor (Studi Pada Ekspor Global Teh Indonesia Periode Tahun 2010-2013). Jurnal Administrasi Bisnis, 35(2), 20-29. Google Scholar

Monita, R., \& Hasmarini, I. M. I. (2021). Analisis Faktor-Faktor Yang Mempengaruhi Ekspor Teh Indonesia Ke Malaysia Tahun 1984-2018. Universitas Muhammadiyah Surakarta.Google Scholar

Nachrowi, N. D., \& Usman, H. (2005). Penggunaan Teknik Ekonometri: Pendekatan Populer Dan Praktis Dilengkapi Teknik Analisis Dan Pengolahan Data Dengan Menggunakan Paket Program Spss. Edisi Revisi, Pt Rajagrafindo Persada, Jakarta.Google Scholar

Pambudi, A. D., \& Budiningharto, S. (2011). Analisis Faktor-Faktor Yang Mempengaruhi Ekspor Biji Kakao Indonesia Ke Malaysia Dan Singapura. Universitas Diponegoro.Google Scholar

Puspita, T., \& Ghozali, I. (2011). Analisis Faktor-Faktor Yang Mempengaruhi Tingkat Underpricing Saham Pada Saat Initial Public Offering (Ipo) Di Bursa Efek Indonesia Periode 2005-2009. Universitas Diponegoro.Google Scholar

Saragih, R., Agusta, I., \& Sjaf, S. (2020). Development Communication Convergence: Problems In Village Transfer Management In Simalungun Regency, North Sumatra. International Journal Of Progressive Sciences And Technologies, 20(2), 40-49.Google Scholar

Sevianingsih, Y. E., Yulianto, E., \& Pangestuti, E. (2016). Pengaruh Produksi, Harga 
Teh Internasional Dan Nilai Tukar Terhadap Volume Ekspor Teh Indonesia (Survey Volume Ekspor Teh Indonesia Periode 2010-2014). Jurnal Administrasi Bisnis, 40(2), 24-31.Google Scholar

Sidabalok, S. (2017). Analisis Faktor-Faktor Yang Mempengaruhi Ekspor Komoditas Teh Indonesia. Jurnal Penelitian Pendidikan Sosial Humaniora, 2(2), 276281.Google Scholar

Sukirno, S. (2011). Makroekonomi Teori Pengantar Edisi Ketiga, Jakarta. Rajawali Pers.Google Scholar

Suminar, G., \& Hms, I. M. (2019). Analisis Faktor-Faktor Yang Mempengaruhi Produksi, Harga Teh Internasional Dan Nilai Tukar Terhadap Volume Ekspor Teh Indonesia. Universitas Muhammadiyah Surakarta.Google Scholar

Suryanto, E., \& Sasana, H. (2017). Analisis Pengaruh Pdb, Populasi, Kurs Dan Inflasi Terhadap Impor Di Indonesia. Fakultas Ekonomika Dan Bisnis.Google Scholar

Wahidmurni, W. (2017). Pemaparan Metode Penelitian Kualitatif.Google Scholar

Yanita, M., Napitupulu, D. M. T., \& Rahmah, K. (2019). Analysis Of Factors Affecting The Competitiveness Of Indonesian Crude Palm Oil (Cpo) Export In The Global Market. Indonesian Journal Of Agricultural Research, 2(3), 156-169.Google Scholar

Zakariya, M. L., Al Musadieq, M., \& Sulasmiyati, S. (2016). Pengaruh Produksi, Harga, Dan Nilai Tukar Terhadap Volume Ekspor (Studi Pada Volume Ekspor Biji Kakao Indonesia Periode Januari 2010-Desember 2015). Jurnal Administrasi Bisnis, 40(2), 139-145. Google Scholar

\section{Copyright holder :}

Isal Rahmatul Putri, Wiwin Priana, Muhammad Wahed (2021)

First publication right:

Jurnal Syntax Admiration

This article is licensed under: 